\title{
The Severity Assessment of Critically ill Preeclamptic Women: A Case-Control Study*
}

\author{
A Avaliação de Gravidade de Mulheres em Estado \\ Grave por Pré-eclâmpsia: Estudo Caso-Controle
}

João Paulo Souza', Geraldo Duarte², Aníbal Basile-Filho ${ }^{3}$

\section{RESUMO}

JUSTIFICATIVA E OBJETIVOS: A avaliação de gravidade e do prognóstico de pacientes obstétricas através de escores é ainda tema controverso, sendo escassa a informação sobre mulheres com pré-eclâmpsia. Esta é uma das maiores causas de morbidade materna grave e de mortalidade materna, além de ser também uma das principais causas de internação obstétrica em UTI. Os objetivos deste estudo foram avaliar e comparar a aplicação do APACHE II, SAPS II e MPM II em população de mulheres com pré-eclâmpsia e em população feminina não-obstétrica.

MÉTODO: Foi realizado um estudo caso-controle com 28 mulheres pré-eclâmpticas e 56 pacientes femininas não-obstétricas admitidas em unidade de terapia intensiva geral, num período de 10 anos. A acurácia preditiva dos sistemas de avaliação prognóstica foi estimado através da área sob a curva ROC.

RESULTADOS: A taxa de mortalidade no grupo de estudo foi de $21,4 \%(6: 28)$ e $35,7 \%$ (20:56) no grupo controle, com OR $=0,49(95 \% \mathrm{Cl}=0,17-1,41)$. As principais causas de admissão à UTI de mulheres com

1. Ex-Residente de Ginecologia e Obstetrícia e de Medicina Intensiva do HCFMRP-USP, Supervisor da Unidade de Terapia Intensiva do CAISM-UNICAMP, Especialista em Medicina Intensiva e Tocoginecologia, Mestre em Tocoginecologia e Doutorando em Tocoginecologia pela FCM - UNICAMP

2. Professor Titular de Ginecologia e Obstetrícia da FMRP-USP

3. Professor associado de Cirurgia e Anatomia, Chefe da Disciplina de Terapia Intensiva da FMRP-USP

*Recebido da Faculdade de Medicina de Ribeirão Preto da Universidade de São Paulo (FMRP-USP), Ribeirão Preto, SP

Apresentado em 01 de fevereiro de 2006

Aceito para publicação em 17 de fevereiro de 2006

Endereço para correspondência:

Dr. João Paulo Souza

Rua Antônio Luiz Carbone, 126

Cidade Universitária II - Barão Geraldo

13083-050 Campinas, SP

E-mail: souzajpd@unicamp.br pré-eclâmpsia foram: síndrome HELLP, coma e edema pulmonar agudo. Na população com pré-eclâmpsia, apenas o escore MPM II mostrou uma área sob a curva ROC estatisticamente diferente de 0,500 , enquanto que no grupo controle, todos os sistemas de escore apresentaram uma área estatisticamente diferente de 0,500 .

CONCLUSÕES: De acordo com os achados do presente estudo, concluímos que a aplicação do sistema APACHE II e SAPS II para avaliar mulheres com préeclâmpsia em estado grave de saúde é possivelmente inapropriado.

Unitermos: escores de gravidade, pré-eclâmpsia, morbidade materna grave, terapia intensiva obstétrica.

\section{SUMMARY}

BACKGROUND AND OBJECTIVES: The assessment of illness severity and prognosis of obstetric patients by scoring systems is still a controversial issue. Preeclampsia is a leading cause of severe maternal morbidity and mortality, and a major cause of obstetric admission to intensive care unit. There is paucity of data regarding the predictability of critically ill preeclamptic women and the application of scoring systems to this population. This study aimed to evaluate and compare the application of APACHE II, SAPS II and MPM II scoring systems between a preeclamptic population and a non obstetric female population.

METHODS: A case-control study was conducted on 28 preeclamptic women and 56 non obstetric female patients, admitted to a general intensive care unit over a period of 10 years. The predictive accuracy of the prognostic evaluation systems was estimated by the area under the receiver operator characteristic curve.

RESULTS: The mortality rate was $21.4 \%$ (6:28) for the study group and $35.7 \%$ (20:56) for the control group, with an $\mathrm{OR}=0.49(95 \% \mathrm{Cl}=0.17-1.41)$. The main causes of ICU admission of preeclamptic women were 
HELLP syndrome, coma and pulmonary edema. In the preeclamptic population, only the MPM II score showed an area under the ROC curve statistically different from 0.500 , while in the control group, all scoring systems had their areas under the ROC curves statistically different from 0.500 .

CONCLUSIONS: The application of APACHE II and SAPS II to evaluate critically ill preeclamptic women may be not appropriate.

Key Words: Critical care obstetrics, near miss maternal morbidity, preeclampsia, scoring systems

\section{INTRODUCTION}

More than half million women die every year of causes related to pregnancy. Most of these deaths are avoidable and $98 \%$ of them occur in developing countries ${ }^{1,2}$. One of the strategies in the fight against maternal mortality has been the offer of emergency obstetrical care and, within this context; the offer of advanced life support can be of great value 1 . In order to properly evaluate the quality of the offered care, treatment protocols, and the impact of new therapeutic modalities, it is important to assess the illness severity ${ }^{3}$, even of obstetric patients. The illness severity of critically ill patients is usually assessed by scoring systems based on physiological and epidemiological variables. Among these systems the Acute Physiology and Chronic Health Evaluation II (APACHE II), the Simplified Acute Physiology Score II (SAPS II) and the Mortality Probability Models II (MPM II) are widely employed ${ }^{4-6}$.

However, the assessment of illness severity and prognosis of obstetric patients by scoring systems is still a controversial issue ${ }^{7,8}$. For instance, Koch $^{9}$ evaluated the predictive capacity of the APACHE II in critically ill obstetrical patients and concluded that it was difficult to predict the prognosis of these patients at any time during their acute disease, and considered these patients "non-prognosticable". In contrast, another study, which also evaluated the APACHE II applied to obstetrical patients, concluded that obstetrical patients had a better prognosis than predicted ${ }^{10}$. A study testing the predictive ability of the APACHE II, SAPS II and MPM II, concluded that all three systems had the same ability to evaluate the prognosis of obstetrical and non-obstetrical patients ${ }^{11}$.

In the core of this controversy, it is the possible loss of ability on the assessment of severity and prognosis of obstetrical patients by scoring systems. It could be explained by two facts: the women's physiology during the gravid-puerperal cycle is changed and there are specific diseases and conditions occurring in this special period of women's life ${ }^{12,13}$. In this context, preeclampsia is a multisystem disorder, specific to human pregnancy, remaining as one of the most severe threatening events for safe motherhood ${ }^{14}$. It is a leading cause of severe maternal morbidity and mortality, and a major cause of obstetric admission to intensive care unit ${ }^{15-17}$. Nevertheless, there is paucity of data regarding the predictability of critically ill preeclamptic women and the application of scoring systems to this population.

We performed this study to evaluate the application of APACHE II, SAPS II and MPM II scoring systems to the preeclamptic population, comparing to a non-obstetric female population, both admitted to a general Intensive Care Unit (ICU).

\section{METHODS}

This is a case-control study conducted at the Ribeirão Preto Medical School University Hospital, the tertiary reference to a region of approximately three million inhabitants, in Brazil. We identified all preeclamptic/ eclamptic women admitted to the ICU, between January 1, 1991 and December 31, 2000. We adopted a definition of preeclampsia encompassing two elements: new-onset hypertension (defined as a sustained blood pressure $\geq 140 / 90 \mathrm{mmHg}$ in a previously normotensive woman); and new onset of proteinuria (defined as $>300$ $\mathrm{mg} / 24 \mathrm{~h}$ or $\geq 2+$ on a clean-catch urinalysis in the absence of urinary tract infection $)^{18}$. Eclampsia refers to the occurrence of at least one generalized convulsion or coma in the setting of preeclampsia and in the absence of other neurologic conditions ${ }^{19}$. We also identified two non-pregnant patients aged 14 to 45 years consecutively admitted to the ICU after each preeclamptic/eclamptic patient, so that each patient in the preeclamptic/eclamptic group (cases) could be related to two non-obstetrical controls. The Ethics Committee of the Hospital approved this study.

The following data were extracted from medical records and compared: age, patient health condition at the end of her stay in the ICU, route of delivery, cause of admission to the ICU, clinical indicators (heart rate, temperature, arterial pressure, and respiratory frequency), laboratory data (arterial blood gases, electrolytes, urea, creatinine, bilirubin, hematocrit, white cell counts, and prothrombin time) and patient score on the Glasgow coma scale upon admission to the ICU and 24 hours later. To obtain the prognostic evaluation of these syste- 
ms, the worst values observed during the first 24 hours of hospitalization were considered.

The APACHE II, SAPS II and MPM II score of each patient were calculated, according to the instructions of Knaus et al. ${ }^{4}$, Le Gall et al. ${ }^{5}$ and Lemeshow et al. ${ }^{6}$, respectively.

The mortality rate, odds ratio (OR) and 95\% confidence interval $(95 \% \mathrm{Cl})$ were determined for each group. Means of scores were calculated and compared for the study and control groups.

To assess the death predictive ability of these scoring systems we constructed curves of the receiver operator characteristic $(\mathrm{ROC})$ type and determined the areas under the curves ${ }^{20}$. Computational support was provided by the software MedCalc (Mariakerke, Belgium), and we considered the statistical significance when $\mathrm{p}<0.05$.

\section{RESULTS}

During the ten years reviewed, 28,660 women were delivered at the institution and a total of 68 obstetric patients were admitted to the ICU. Twenty eight women admitted to the ICU had developed preeclampsia or eclampsia. The mean age $( \pm S D)$ was $27 \pm 6.5$ years for the women in the study group and $29.6 \pm 8.2$ years for the women in the control group. The mean length of stay $( \pm S D)$ in the ICU was $5.7 \pm 6$ days for the preeclamptic women and $5.1 \pm 6$ days for the non-preeclamptic women.

Considering the study group, twenty-one cesarean sections were performed (75\%) and two women were submitted to hysterectomy. Only three women (10.7\%) were admitted to the ICU before delivery.

There were 23 maternal deaths, six of them among preeclamptic/eclamptic women. The mortality rate was $21.4 \%$ (6:28) for the study group and 35.7\% (20:56) for the control group, with an OR $=0.49(95 \% \mathrm{Cl}=0.17$ 1.41). The diagnostic categories of preeclamptic and non-preeclamptic women are listed in table 1. The major cause of ICU admission among the preeclamptic/ eclamptic population was HELLP syndrome, followed by coma and pulmonary edema. Among the non-obstetrical population, the major cause of ICU admission was sepsis, followed by respiratory failure and postoperative status. Table 2 shows the means of score obtained by the prognostic evaluation systems studied. Both populations presented similar scores in the admission to the ICU. The areas under the ROC curves for the APACHE II, SAPS II and MPM II scores are presented in table 3. In the preeclamptic population, only the MPM II score showed an area under the ROC curve statistically different from 0.500 , while in the control group, all the three scoring systems had their areas under the ROC curves statistically different from 0.500 .

Table 1 - Distribution of the Causes of Admission to the ICU of Preeclamptic and Non-Obstetrical Female Patients

\begin{tabular}{l|c|c|c}
\multicolumn{2}{c|}{$\begin{array}{c}\text { Preeclamptic } \\
\text { Patients }\end{array}$} & \multicolumn{2}{c}{$\begin{array}{c}\text { Non-Obstetrical } \\
\text { Female Patients }\end{array}$} \\
\hline Causes & $\mathrm{n}(\%)$ & Causes & $\mathrm{n}(\%)$ \\
HELLP syndrome & $8(28.6)$ & Sepsis & $16(28.6)$ \\
Coma & $6(21.4)$ & $\begin{array}{c}\text { Respiratory } \\
\text { failure }\end{array}$ & $13(23.2)$ \\
& & Postoperative & $12(21.4)$ \\
Pulmonary edema & $4(14.3)$ & Neoplasia & $4(7.1)$ \\
Convulsions & $3(10.7)$ & PTE & $3(5.4)$ \\
Severe hypertension & $2(7.1)$ & Others & $8(14.3)$ \\
Hemorrhage & $2(7.1)$ & & \\
Others & $3(10.7)$ & & $56(100.0)$ \\
Total & $28(100.0)$ & Total & 56 \\
\hline
\end{tabular}

Table 2 - Means of Scores Obtained with APACHE II, SAPS II and MPM II on Preeclamptic and Non-Obstetrical Female Patients admitted to Intensive Care Unit

\begin{tabular}{l|c|c|c}
\hline & $\begin{array}{c}\text { Preeclamptic } \\
\text { Women* }^{*}\end{array}$ & $\begin{array}{c}\text { Non-Obstetrical } \\
\text { Female Patients* }\end{array}$ & p value \\
\hline APACHE II & $15 \pm 6$ & $15 \pm 8$ & NS \\
SAPS II & $32 \pm 13$ & $34 \pm 19$ & NS \\
MPM II & $-2.37 \pm 1.37$ & $-2.27 \pm 1.53$ & NS \\
\hline
\end{tabular}

*Values expressed in Mean \pm SD

Table 3 - Areas under the ROC Curves among Preeclamptic Patients and Non-Obstetrical Female Patients

\begin{tabular}{l|c|c|c}
\hline & AUROC & SD & 95\% CI \\
\hline Preeclamptic Patients & & & \\
APACHE II & 0.591 & 0.137 & $0.390-0.771$ \\
SAPS II & 0.602 & 0.137 & $0.401-0.781$ \\
MPM II & 0.758 & 0.124 & $0.559-0.898$ \\
& & & \\
Non-Obstetrical Female & & & \\
Patients & & & \\
APACHE II & 0.797 & 0.067 & $0.668-0.892$ \\
SAPS II & 0.864 & 0.056 & $0.746-0.941$ \\
MPM II & 0.867 & 0.056 & $0.749-0.942$ \\
\hline
\end{tabular}

AUROC: Area Under the ROC curve; SD: Standard Deviation; 95\%Cl: 95\% confidence interval

\section{DISCUSSION}

Women presenting with severe preeclampsia may develop serious complications with high risk of maternal death and the use of APACHE II and SAPS II to evaluate the critically ill preeclamptic women may be not appropriate. In many developing countries, including Brazil, 
depending on different circumstances, the availability of critical care may be sometimes insufficient. In this study, only $0.1 \%(28 / 28660)$ of the deliveries resulted in ICU admission for preeclampsia, nevertheless, it was observed a high maternal mortality rate $(21.4 \%)$. The low ICU utilization combined with the high maternal mortality observed may be suggestive of the occurrence of possible delays in the offer of critical care. The rare ICU utilization before delivery can corroborate the former observation, once it is probable that, in many cases, the severe disease would already be installed before the end of gestation. According to this, the critical care should be inserted in the strategy of fight against maternal mortality, among the improvement of the referral process throughout the health care system.

By other side, to properly evaluate the results of scientific research with critically ill patients, it is very important to obtain a stratification of severity, principally if one of the outcomes of interest is related to mortality or severe morbidity. Otherwise, for example, in a study testing a new treatment, it is difficult to assure that a certain outcome was an effect of the new treatment and not due to a pre-existing difference in the level of severity. The severity may play a role of confounder - a "severity bias" - in such kind of study. In this study, we observed that two widely used scoring systems for critically ill patients (APACHE II and SAPS II) revealed a significant incapacity to assess the preeclamptic women requiring critical care. Although not statistically significant, the MPM II scoring system also presented a trend of less accuracy in the preeclamptic population.

Our findings are an additional argument to the message of caution regarding to the application of scoring system to obstetric populations, previously expressed elsewere ${ }^{8}$. However, considering the role of the scoring systems, our findings should also serve as a stimulus to the development of a new and specific scoring system, designed for the obstetrical population, including the preeclamptic women. In this way we would propose to the community dealing with the obstetric critical care the development of such obstetric severity score, perhaps promoting an obstetric upgrade to the Mortality Probability Models II (MPM II). We believe that this new scoring system would be useful to research and to the evaluation of quality of care, allowing the comparison of different settings.

\section{REFERENCES}

01. WHO, UNFPA, UNICEF, World Bank Statement. Reduction of maternal mortality. Geneva, World Health Organization, 1999.

02. WHO. Maternal mortality in 2000: estimates developed by WHO, UNICEF and UNFPA. Geneva, World Health Organization, 2004.

03. Knaus WA - APACHE 1978-2001: The development of a quality assurance system based on prognosis: milestones and personal reflections. Arch Surg, 2002;137:37-41.

04. Knaus WA, Draper EA, Wagner DP et al - APACHE II: A severity of disease classification system. Crit Care Med, 1985;13:818-829.

05. Le Gall J-R, Lemeshow S, Saulnier F - A new simplified acute physiology score (SAPS II) based on a European/North American multicenter study. JAMA, 1993;270:2957-2963.

06. Lemeshow S, Teres D, Klar J et al - Mortality probability models (MPM II) based on an international cohort of intensive care unit patients. JAMA, 1993;270:2478-2486.

07. Ridley SA - Uncertainty and scoring systems. Anaesthesia, 2002;57:761767.

08. Gopalan PD, Muckart DJ - The critically ill obstetric patient: what's the score? Int J Obstet Anesth, 2004;13:144-145.

09. Koch KA, Rodeffer HD - Critically ill obstetrical patients: outcome and predictability. Crit Care Med, 1988;16:409.

10. Lewinsohn G, Herman A, Leonov Y et al - Critically ill obstetrical patients: outcome and predictability. Crit Care Med, 1994;22:1412-1414.

11. El-Solh AA, Grant BJB - A comparison of severity of illness scoring systems for critically ill obstetric patient. Chest, 1996;110:1299-1304.

12. Cerra FB, Negro F, Abrams J - APACHE II score does not predict multiple organ failure or mortality in postoperative surgical patients. Arch Surg, 1990;125:519-522.

13. Godeau B, Boudjadja A, Dhainaut JF et al - Outcome of patients with systemic rheumatic disease admitted to medical intensive care units. Ann Rheum Dis, 1992;51:627-631.

14. Sibai B, Dekker G, Kupferminc M - Preeclampsia. Lancet, 2005;365:785799.

15. Graham SG, Luxton MC - The requirement for intensive care support for the pregnant population. Anaesthesia, 1989;44:581-584.

16. Mabie WC, Sibai BM - Treatment in an obstetric intensive care unit. Am J Obstet Gynecol, 1990;162:1-4.

17. Kirshon B, Hinkley CM, Cotton DB et al - Maternal mortality in a maternal-fetal medicine intensive care unit. J Reprod Med, 1990;35:25-28.

18. Report of the National High Blood Pressure Education Program Working Group on high blood pressure in pregnancy. Am J Obstet Gynecol, 2000;183:S1-S22.

19. Norwitz ER, Hsu CD, Repke J - Acute complications of preeclampsia. Clin Obstet Gynecol, 2002;45:308-326.

20. Hanley JA, Mc Neil BJ - The meaning and use of the area under the receiver operating characteristic (ROC) curve. Radiology, 1982;143:29-36. 